\title{
Konseling gizi mempengaruhi kualitas diet pasien diabetes mellitus tipe 2 di RSUP Dr.Sardjito Yogyakarta
}

\author{
Nutritional counseling affected the diet quality of type 2 diabetes mellitus patients at Dr. Sardjito \\ Hospital Yogyakarta
}

Stefania Widya $S^{1}$, Luthfan Budi $P^{2}$, Martalena Br Purba ${ }^{3}$

\begin{abstract}
Background: One key factor in diabetes mellitus management is improvement of diet quality. Nutrition counseling is one of medical nutritional therapy that is given to improve dietary pattern and lifestyle in patients with diabetes mellitus.

Objectives: To assess the effect of both individual and group counseling to improve diet quality in patient with diabetes mellitus.

Methods: This research used quasi-experiment method with non-randomized control group pretest-posttest design. The diet qualities of 54 respondens with diabetes mellitus were explored using semi-quantitative food frequency questionnaire (SQ-FFQ) before converted to diet quality score using healthy eating index (HEI) standard scores. Intervention group were given individual nutrition counseling, then they were formed into a group consists of 2-5 subjects per group to make focus group discussion. Intervention group were monitored via telephone or sms every week. In fourth week, the diet quality of both control and intervention group will be re-evaluated.

Results: Proportion of subjects that have adequate diet quality improved in intervention group ( $p=0.0235)$ after receiving individual and group counseling. In the other hand, diet quality in control group tended to decrease $(p=0.0339)$ in the end of the research. The effectiveness of nutrition counseling in improving HEl scores was $73 \%$.
\end{abstract}

Conclusions: The combination of individual and group counseling could improve diet quality in patient with diabetes mellitus.

KEYWORDS: diabetes mellitus, diet quality, nutrition counseling

\begin{abstract}
ABSTRAK
Latar belakang: Salah satu faktor kunci dalam penatalaksanaan penyakit diabetes mellitus adalah perbaikan kualitas diet. Konseling gizi merupakan salah satu upaya terapi gizi medis yang diberikan untuk memperbaiki pola makan dan gaya hidup pasien diabetes mellitus.

Tujuan: Menguji efek konseling gizi individu dan kelompok untuk memperbaiki kualitas diet pada pasien diabetes mellitus.

Metode: Penelitian ini menggunakan metode kuasi eksperimen dengan rancangan non-randomized control group pretest-posttest. Kualitas diet 54 responden yang mengalami diabetes mellitus akan digali menggunakan semi-quantitative food frequency questionnaire (SQ-FFQ) sebelum dikonversikan menjadi skor kualitas diet berdasarkan standar perhitungan skor healthy eating index (HEI). Kelompok perlakuan kemudian akan diberi konseling gizi secara individu. Kemudian pasien dibentuk menjadi kelompokkelompok kecil yang terdiri dari 2 hingga 5 orang untuk melakukan diskusi kelompok terarah. Setiap minggu pasien akan diingatkan tentang dietnya melalui telepon atau pesan singkat. Pada minggu keempat, kualitas diet pasien kelompok kontrol dan kelompok perlakuan akan kembali dievaluasi.
\end{abstract}

\footnotetext{
${ }_{1}$ Program Studi IImu Gizi Fakultas Kesehatan Masyarakat Universitas Airlangga, Kampus C Mulyorejo Surabaya 60115, e-mail: stefania.widya@gmail.com

2 RSUP Dr. Sardjito Bagian IImu Penyakit Dalam, JI. Kesehatan 1, Yogyakarta

${ }^{3}$ RSUP Dr. Sardjito, JI. Kesehatan 1, Yogyakarta
} 
Hasil: Proporsi subjek yang memiliki kualitas diet baik meningkat pada kelompok perlakuan sesudah menerima intervensi berupa konseling gizi individu dan kelompok, sedangkan pada kelompok kontrol cenderung mengalami penurunan di akhir penelitian. Tingkat keberhasilan konseling gizi dalam meningkatkan skor $\mathrm{HEl}$ sebesar $73 \%$.

Kesimpulan: Gabungan konseling gizi secara individu dan kelompok dapat meningkatkan kualitas diet pada pasien diabetes mellitus tipe 2.

KATA KUNCI: diabetes mellitus, kualitas diet, konseling gizi

\section{PENDAHULUAN}

Pengaturan diet merupakan salah satu hal yang penting dalam manajemen diabetes mellitus. Tanpa adanya pengaturan diet yang adekuat, pasien diabetes berpeluang besar mengalami berbagai penyakit komplikasi diabetes, baik makroangiopati, mikroangiopati, maupun neuropati (1).

Tidak hanya konsumsi gula, konsumsi zat gizi lain seperti lemak, serat, antioksidan, dan lain-lain juga sangat berpengaruh terhadap progresivitas penyakit diabetes mellitus (2). Telah banyak penelitian yang mengangkat hubungan antara konsumsi zat gizi tertentu dengan kejadian diabetes mellitus. Namun demikian, hingga saat ini, penelitian mengenai kualitas diet secara keseluruhan pada pasien diabetes mellitus ini masih sangat sedikit.

Kualitas diet yang baik, akan membantu pasien mengontrol kadar gula darah dan menghindari berbagai komplikasi yang mungkin timbul akibat penyakit ini. Penelitian di Spanyol (3) menunjukkan kualitas diet yang rendah pada pasien diabetes mellitus dengan obesitas, sedangkan di Perancis melaporkan bahwa pasien diabetes mellitus mengalami kesulitan mencapai tingkat kepatuhan diet yang diinginkan (4). Healthy eating index (HEI) merupakan salah satu alat yang dikembangkan oleh United State Department of Agriculture (USDA) untuk mengukur kualitas diet seseorang (5). Semakin besar nilai HEI seseorang, semakin baik kualitas dietnya (2). Gambaran perubahan kualitas diet pasien sebelum dan sesudah mendapat konseling gizi dapat menjadi salah satu indikator keberhasilan penatalaksanaan penyakit diabetes mellitus.

Kegiatan konseling merupakan salah satu strategi penatalaksanaan penyakit diabetes mellitus. Tujuan konseling gizi adalah mengubah porsi dan pola makan pasien diabetes $(6,7)$. Jenis konseling individu masih sering digunakan dalam praktik, namun konseling kelompok mulai menjadi pertimbangan. Konseling kelompok dinilai lebih efisien dan memberikan banyak sumber daya dan sudut pandang (8). Pada beberapa penelitian, penggunaan konseling kelompok diketahui menghasilkan keluaran terkait gizi yang lebih baik dibanding konseling individu dengan attrition rate sebesar $>30 \%$ (9). Pada kasus-kasus permasalahan tertentu, terkadang kombinasi konseling individu dan kelompok merupakan alternatif terbaik (8). Tujuan penelitian ini adalah untuk mengetahui efek konseling gizi terhadap kualitas diet pasien diabetes mellitus di RSUP Dr. Sardjito Yogyakarta.

\section{BAHAN DAN METODE}

Penelitian ini menggunakan metode kuasi eksperimen dengan rancangan non-randomized control group pretest-postest. Subjek dalam penelitian ini adalah pasien diabetes tanpa komplikasi nefropati dan hiperurisemia di Klinik Endokrin Poliklinik Penyakit Dalam RSUP Dr. Sardjito Yogyakarta selama periode Februari hingga April 2013.

Sebanyak 54 responden yang terbagi dalam kelompok kontrol dan kelompok perlakuan akan diwawancara menggunakan kuesioner semiquantitative food frequency questionnaire (SQ-FFQ) pada awal dan akhir penelitian. Kelompok perlakuan selanjutnya akan menerima sebanyak 2 tahap, yaitu konseling individu mengikuti standar konseling gizi bagi pasien diabetes mellitus di RSUP Dr. Sardjito Yogyakarta dan konseling kelompok berupa diskusi kelompok terarah, sedangkan kelompok kontrol tidak mendapatkan konseling.

Konseling individu diberikan oleh peneliti dengan alat bantu daftar bahan penukar dan leaflet. Setelah mendapat konseling individu, pada hari yang 
sama dilakukan pula konseling kelompok dalam diskusi kelompok terarah yang difasilitasi oleh peneliti. Pada penelitian ini, diperoleh beberapa kelompok dengan setiap kelompok diskusi terdiri dari 2 hingga 5 orang peserta. Setiap minggu pasien akan diingatkan kembali tentang dietnya melalui telepon atau sms. Pada minggu ke empat, subjek akan diwawancara kembali menggunakan kuesioner yang sama untuk mengevaluasi kualitas dietnya.

Pada perhitungan kualitas diet, asupan diet sehari dan komponen-komponen zat gizi yang dikonsumsi subjek dihitung dengan menggunakan software Nutrisurvey 2007. Setelah diketahui jumlah asupan energi dan frekuensi konsumsi bahan makanan sesuai pengelompokan dalam HEI, maka skor untuk setiap komponen akan dihitung menggunakan rumus sebagai berikut (10).

$$
\left(\sum(F)_{\text {set }} / \sum(E)_{\text {set }}\right) \rightarrow \text { Assign score } \text { set }
$$

Keterangan:

$\Sigma(F)_{\text {set }}$ : total asupan buah dalam 1 set makanan (total asupan dapat diganti berdasarkan komponen makanan yang ingin diukur nilainya).

$\Sigma(E)_{\text {set }}$ : total energi 1 dalam set makanan

Kualitas skor HEI dibagi menjadi 3 kategori yaitu: nilai HEI 80-100 (kualitas diet pasien adekuat atau baik), 60-79,9 (kualitas diet rata-rata atau biasa), $<60$ (kualitas diet pasien buruk). Efektivitas konseling dihitung dengan menggunakan rumus efektivitas= 100(1-(P1/P2), dengan $\mathrm{P} 1$ yaitu proporsi pada kelompok perlakuan dan $\mathrm{P} 2$ yaitu proporsi pada kelompok kontrol.

Skor akhir HEI dan nilai perubahan skor HEI sebelum dan sesudah intervensi pada masingmasing kelompok akan dihitung menggunakan two samples independent $t$-test dengan menggunakan software STATA edisi ke-11, sedangkan kualitas diet yang telah dikategorikan berdasarkan skor HEl akan dianalisis menggunakan Wilcoxon Mann Whitney test. Penelitian ini telah memperoleh surat persetujuan etik (ethical clearance) dari Komisi Etik Penelitian Kedokteran dan Kesehatan Fakultas Kedokteran Universitas Gadjah Mada Yogyakarta dengan nomor Ref: KE/FK/147/EC tahun 2013.

\section{HASIL}

Karakteristik demografis responden yang berpartisipasi dalam penelitian ini digambarkan dalam beberapa variabel, yaitu: usia, jenis kelamin, lama penyakit, pendidikan, pekerjaan, dan jenis komplikasi, Gambaran karakteristik dasar subjek dapat dilihat pada Tabel 1.

Proses matching variabel usia dan jenis kelamin telah dilakukan selama proses pengambilan data. Tidak ditemukan perbedaan proporsi maupun rerata yang signifikan pada berbagai macam karakteristik demografis seperti usia, jenis kelamin, pendidikan, pekerjaan, dan lama penyakit. Walau demikian, ada perbedaan proporsi jenis komplikasi yang signifikan pada kelompok kontrol dan perlakuan $(p<0,001)$. Pada kelompok kontrol lebih banyak subjek yang memiliki lebih dari 2 jenis komplikasi $(40,74 \%)$, sedangkan pada kelompok perlakuan subjek tanpa komplikasi lebih banyak ditemukan (66,67\%). Data antropometri seperti berat badan, tinggi badan, dan indeks massa tubuh hanya terdapat pada kelompok perlakuan untuk kepentingan konsultasi gizi. Data ini tidak digali pada kelompok kontrol.

Tabel 2 menunjukkan terjadinya penurunan atau peningkatan asupan pada beberapa jenis bahan makanan dan zat gizi berdasarkan komponen HEI. Pada kelompok kontrol, terjadi penurunan asupan biji-bijian utuh, sayuran, dan buah utuh serta peningkatan asupan sodium yang cukup signifikan. Sebaliknya, kelompok perlakuan mengalami peningkatan yang cukup signifikan dari segi asupan energi, total sayuran dan sayuran berwarna, total buah dan buah utuh, daging dan kacang-kacangan, dan susu $(p<0,05)$.

Penilaian kualitas diet subjek penelitian dilakukan dengan mencari rerata asupan bahan makanan tertentu per 1.000 Kalori yang dikonsumsi setiap harinya. Tabel 3 di bawah ini menunjukkan rerata perubahan kualitas diet pada masingmasing kelompok perlakuan sebelum dan sesudah intervensi.

Sebelum pemberian intervensi, kualitas diet subjek berdasarkan standar penilaian HEI pada kelompok kontrol lebih baik dibanding kelompok perlakuan $(p=0,0228)$. Di akhir penelitian, terjadi 
Tabel 1. Karakteristik dasar subjek penelitian

\begin{tabular}{|c|c|c|c|}
\hline \multirow[b]{2}{*}{ Variabel } & \multicolumn{2}{|c|}{ Perlakuan } & \multirow[b]{2}{*}{$\mathbf{p}$} \\
\hline & $\begin{array}{c}\text { Tidak diberi } \\
\text { konseling }(n=27) \\
n(\%)\end{array}$ & $\begin{array}{c}\text { Diberi konseling } \\
(n=27) \\
n(\%)\end{array}$ & \\
\hline Usia (rerata \pm SD tahun) & $57,93 \pm 10,57$ & $58,19 \pm 2,07$ & 0,9292 \\
\hline \multicolumn{4}{|l|}{ Jenis kelamin } \\
\hline Pria & $8(29,63)$ & $8(29,63)$ & \multirow[t]{2}{*}{1,000} \\
\hline Wanita & $19(70,37)$ & $19(70,37)$ & \\
\hline Lama DM (tahun) & $9,53 \pm 8,30$ & $9,20 \pm 6,53$ & 0,8714 \\
\hline \multicolumn{4}{|l|}{ Pendidikan } \\
\hline Tidak tamat SD & $2(7,41)$ & $1(3,70)$ & \multirow{5}{*}{0,920} \\
\hline SD & $2(7,41)$ & $3(11,11)$ & \\
\hline SMP & $3(11,11)$ & $4(14,81)$ & \\
\hline SMA & $11(40,74)$ & $9(33,33)$ & \\
\hline Akademi/PT & $9(33,3)$ & $10(37,04)$ & \\
\hline \multicolumn{4}{|l|}{ Pekerjaan } \\
\hline PNS & $4(14,81)$ & $2(7,41)$ & \multirow{6}{*}{0,359} \\
\hline Wiraswasta & $1(3,70)$ & $6(22,22)$ & \\
\hline Karyawan swasta & $1(3,70)$ & $1(3,70)$ & \\
\hline Petani & $1(3,70)$ & $0(0)$ & \\
\hline Ibu rumah tangga & $11(40,74)$ & $11(40,74)$ & \\
\hline Pensiunan & $9(33,33)$ & $7(25,93)$ & \\
\hline \multicolumn{4}{|l|}{ Komplikasi } \\
\hline Tidak ada komplikasi & $6(22,22)$ & $18(66,67)$ & \multirow{7}{*}{$0,000^{*}$} \\
\hline Retinopati & $1(3,70)$ & $2(7,41)$ & \\
\hline CVD & $1(3,70)$ & $1(3,70)$ & \\
\hline Ulkus & $8(29,63)$ & $1(3,70)$ & \\
\hline Hipertensi & $0(0)$ & $3(11,11)$ & \\
\hline Dislipidemia & $0(0)$ & $1(3,70)$ & \\
\hline Komplikasi $(\geq 2)$ & $11(40,74)$ & $1(3,70)$ & \\
\hline \multicolumn{4}{|l|}{ Antropometri } \\
\hline Berat badan & & $57,85 \pm 6,95$ & \\
\hline Tinggi badan & $\mathrm{N} / \mathrm{A}$ & $160,07 \pm 6,40$ & $\mathrm{~N} / \mathrm{A}$ \\
\hline IMT(18,5-22,9) & & $22,51 \pm 1,53$ & \\
\hline
\end{tabular}

* Signifikan $(p<0,05)$

penurunan skor HEI sebanyak 4,23 $\pm 5,66$ pada kelompok kontrol, namun pada kelompok perlakuan, terjadi peningkatan skor HEI sebesar 5,02 $\pm 5,81$ poin.

Dalam penilaian kualitas diet, skor HEI kemudian akan digolongkan berdasarkan kategorikategori untuk menentukan kualitas diet seseorang. Pada awal penelitian, proporsi kategori kualitas diet pada kelompok kontrol tidak berbeda signifikan dengan kelompok perlakuan $(p<0,05)$. Namun demikian, di akhir penelitian, ada perbedaan proporsi kualitas diet yang cukup signifikan $(p<0,05)$. Terdapat 6 orang subjek kelompok kontrol yang memiliki kualitas diet yang tergolong baik di awal penelitian, tetapi menurun menjadi rata-rata pada akhir penelitian. Lain halnya dengan kelompok perlakuan, apabila sebelum pemberian intervensi seluruh subjek memiliki kualitas diet yang tergolong rata-rata, setelah pemberian intervensi terdapat 5 orang subjek yang mampu meningkatkan kualitas dietnya menjadi lebih baik. Perubahan kualitas diet sebelum dan sesudah intervensi pada kelompok perlakuan ini pun signifikan secara statistik $(p<0,05)$.

Efektivitas konseling gizi meningkatkan skor HEI dan memperbaiki kualitas diet kelompok perlakuan yang dapat dilihat pada Tabel 4 .

Tabel 4 menegaskan bahwa konseling gizi memiliki peranan penting dalam memperbaiki pola makan pasien diabetes. Hal ini disimpulkan 
Tabel 2. Perubahan asupan subjek berdasarkan komponen HEI

\begin{tabular}{lccc}
\hline \multicolumn{1}{c}{ Indikator } & \multicolumn{2}{c}{$\Delta$ Asupan (rerata \pm SD) } & p \\
\cline { 2 - 3 } & $\begin{array}{c}\text { Tidak diberi } \\
\text { konseling }\end{array}$ & Diberi konseling & \\
\hline Energi (kkal) & $9,08 \pm 303,17$ & $204,92 \pm 245,92$ & $0,0059^{*}$ \\
Total biji-bijian (gram) & $-2,19 \pm 54,58$ & $3,38 \pm 99,44$ & 0,9568 \\
Biji-bijian utuh (gram) & $-20,48 \pm 45,96$ & $2,98 \pm 94,35$ & 0,2526 \\
Total sayur (gram) & $-25,98 \pm 51,65$ & $83,01 \pm 58,82$ & $0,0000^{*}$ \\
Sayur berwarna (gram) & $-11,64 \pm 35,86$ & $58,17 \pm 46,64$ & $0,0000^{*}$ \\
Total buah (gram) & $-35,29 \pm 103,80$ & $55,01 \pm 109,97$ & $0,0015^{*}$ \\
Buah utuh (gram) & $-39,38 \pm 92,39$ & $52,40 \pm 107,55$ & $0,0007^{*}$ \\
Daging \& kacang (gram) & $-13,86 \pm 123,86$ & $47,96 \pm 96,70$ & $0,0230^{*}$ \\
Lemak jenuh (gram) & $-0,36 \pm 9,13$ & $1,07 \pm 5,58$ & 0,4900 \\
Susu (mL) & $2,95 \pm 89,56$ & $43,10 \pm 79,61$ & 0,0876 \\
Minyak (gram) & $-2,77 \pm 23,95$ & $2,20 \pm 9,40$ & 0,3223 \\
Sodium (gram) & $1,22 \pm 1,07$ & $0,13 \pm 0,49$ & $0,0000^{*}$ \\
Kalori dari lemak padat & $19,28 \pm 33,54$ & $-13,49 \pm 34,40$ & $0,0004^{*}$ \\
$\quad$ alkohol, dan gula & & & \\
tambahanan (kkal) & & & \\
\hline * Signifikan (p<0,05) & & &
\end{tabular}

Tabel 3. Kualitas diet subjek penelitian

\begin{tabular}{cccc}
\hline & $\begin{array}{c}\text { Tidak diberi } \\
\text { konseling }\end{array}$ & $\begin{array}{c}\text { Diberi } \\
\text { konseling }\end{array}$ & p \\
\hline Skor HEI & & & \\
Sebelum & $73,78 \pm 6,78$ & $70,66 \pm 4,01$ & $0,0228^{*}$ \\
Sesudah & $69,55 \pm 4,75$ & $75,68 \pm 6,49$ & $0,0001^{*}$ \\
$\Delta \mathrm{HEl}$ & $-4,23 \pm 5,66$ & $5,02 \pm 5,81$ & $0,0000^{*}$ \\
Kualitas diet & & & \\
Sebelum & & & \\
Baik & $6(22,22 \%)$ & $0(0)$ & \\
$\quad \begin{array}{l}\text { Rata-rata } \\
\text { Buruk }\end{array}$ & $2(70,37 \%)$ & $27(100,00 \%)$ & $0,1299^{*}$ \\
$\begin{array}{c}\text { Sesudah } \\
\text { Baik }\end{array}$ & $0(7,41 \%)$ & $0(0)$ & \\
Rata-rata & $25(92,59 \%)$ & $22(81,48 \%)$ & $0,0779^{*}$ \\
Buruk & $2(7,41)$ & $0(0)$ & \\
\hline
\end{tabular}

* Signifikan $(p<0,05)$

Tabel 4. Efektivitas konseling gizi terhadap peningkatan skor HEl sesudah pemberian intervensi

\begin{tabular}{lcccc}
\hline & $\begin{array}{c}\text { Tetap } \\
\text { atau } \\
\text { menurun }\end{array}$ & Meningkat & Jumlah Efektivitas \\
\hline $\begin{array}{l}\text { Tidak } \\
\text { diberi } \\
\text { konseling }\end{array}$ & 22 & 5 & 27 & $73 \%$ \\
$\begin{array}{l}\text { Diberi } \\
\text { konseling } \\
\text { Jumlah }\end{array}$ & 6 & 21 & 27 & \\
\hline
\end{tabular}

dari adanya peningkatan skor HEI pada kelompok perlakuan sesudah mendapatkan intervensi berupa konseling gizi. Tingkat keberhasilan konseling gizi dalam meningkatkan skor HEI adalah sebesar $73 \%$.

Gambaran perubahan skor HEl sebelum dan sesudah pemberian intervensi dapat dilihat pada Gambar 1 dan Gambar 2.

\section{BAHASAN}

Diet memiliki peranan penting dalam pencegahan dan pengaturan hiperglikemia dan diabetes. Fokus baru dalam epidemiologi gizi adalah pola makan. Pendekatan pola makan dapat memberikan informasi menyeluruh mengenai interaksi biologis dari komponen zat gizi berbagai kelompok bahan makanan, serta hubungannya dengan berbagai macam gangguan. Pola makan yang buruk dan kualitas diet yang rendah berpotensi menimbulkan penyakit kronis terkait obesitas (11).

Kualitas diet yang baik direfleksikan sebagai pola diet yang ditandai dengan tingginya asupan sayuran, buah-buahan, biji-bijian utuh, asupan alkohol sedang, rendahnya asupan daging merah serta produk olahan daging, garam, minuman 


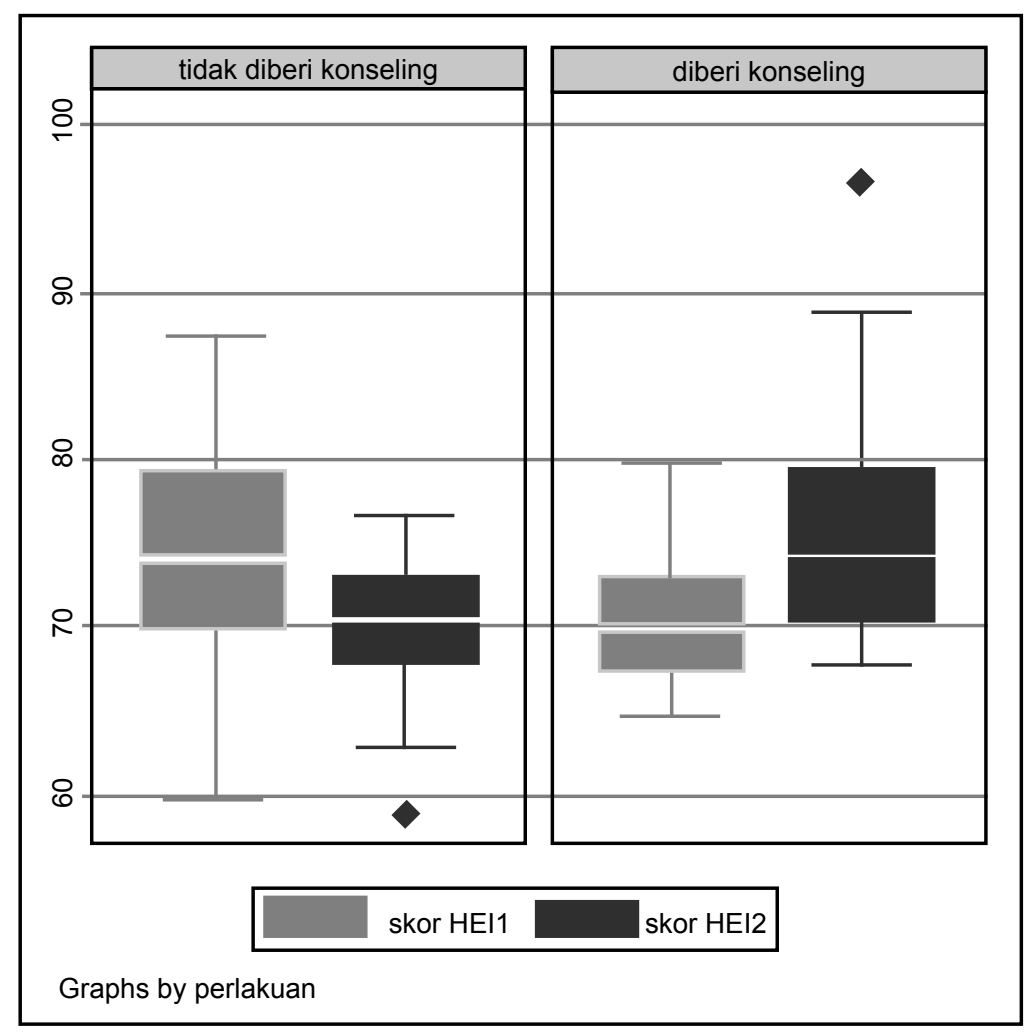

Gambar 1. Kualitas diet subjek sebelum dan sesudah intervensi

manis, dan lemak trans. Tingginya kualitas diet pada laki-laki diabetes dan pre-diabetes dikaitkan dengan penurunan tekanan darah sistolik dan diastolik, total kolesterol, dan gula darah puasa, sedangkan pada wanita, terdapat penurunan kolesterol total, gula darah puasa, kadar insulin plasma puasa, gula darah 2 jam post-prandial, dan peningkatan sensitivitas insulin pada individu dengan kualitas diet yang tinggi (12).

Tidak hanya sebagai upaya preventif, rekomendasi diet sehat untuk masyarakat umum juga sebaiknya diterapkan pada individu dengan diabetes tipe $2(13,14)$. Individu dengan diabetes mellitus memiliki risiko mengalami infark miokardial yang sama besarnya dengan orang yang telah memiliki penyakit kardiovaskular sebelumnya. Pada dasarnya, rekomendasi diet sehat dan seimbang cocok untuk manajemen kedua penyakit ini (15).

Efek menguntungkan dari peningkatan kualitas diet terhadap penyakit diabetes mellitus tipe 2 diperoleh melalui beberapa mekanisme. Magnesium dari kacang dan biji-bijian utuh merupakan kofaktor yang penting dalam ambilan dan oksidasi glukosa sel (16). Serat dari makanan seperti sayur, buah, biji-bijian utuh, dan kacang-kacangan dapat menurunkan absorbsi glukosa intestinal, sehingga meminimalisir terjadinya kenaikan glukosa postpandrial secara mendadak (17). Hal ini dapat memperbaiki kebutuhan insulin dan fungsi sel beta. Polyunsaturated fatty acid (PUFA) dari minyak nabati dan kacang-kacangan menurunkan trigliserida postpandrial dan meningkatkan fluiditas membran sel skeletal otot dan ambilan glukosa dibanding lemak jenuh. Hal ini dapat memperbaiki sensitivitas insulin pada pasien dengan diabetes mellitus $(18,19)$. Protein susu juga memiliki efek dalam menstimulasi sekresi asam amino insulinotropik dan hormon inkretin yang terbukti menurunkan insiden diabetes mellitus tipe 2 pada wanita paruh baya dan lanjut usia. Efek insulinotropik susu ini diduga mempengaruhi toleransi glukosa (20). Kalsium yang terkandung di susu dan produk olahannya telah terbukti menurunkan tekanan darah pada beberapa penelitian kohort (21). Penggunaan lemak tidak jenuh dan tidak terhidrogenasi sebagai sumber utama lemak diet, biji-bijian utuh sebagai bentuk 


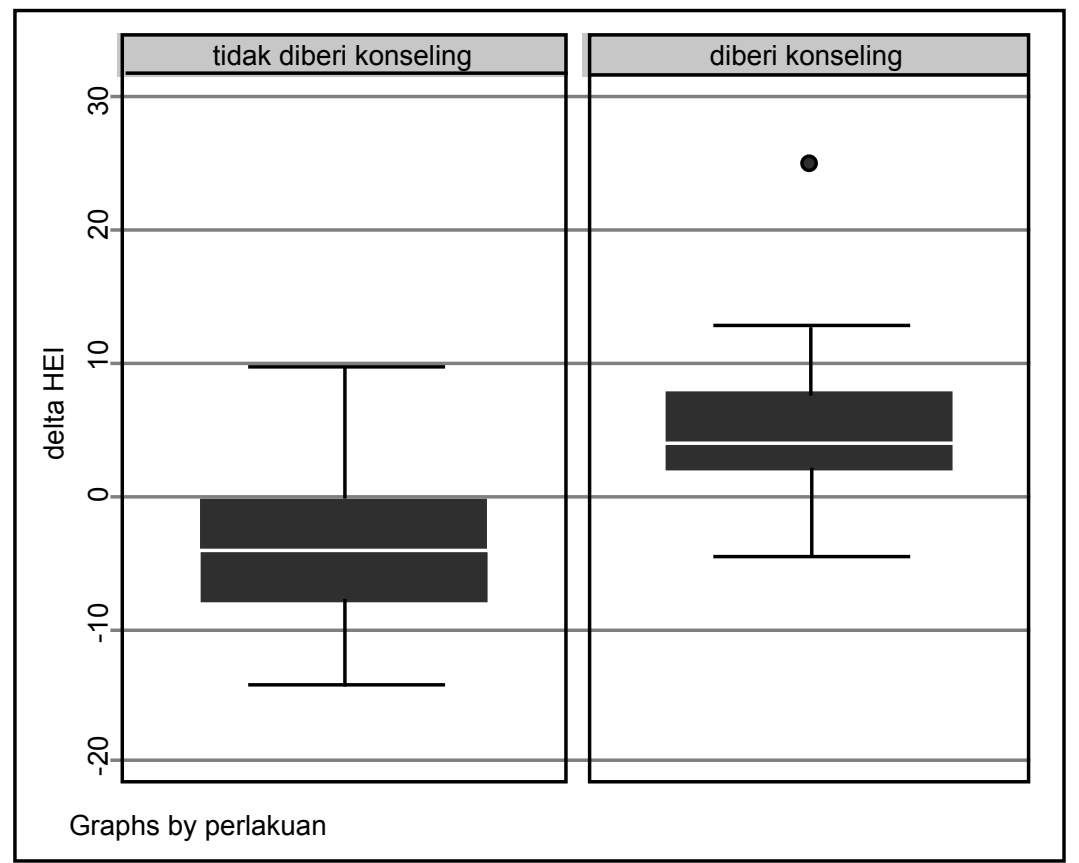

Gambar 2. Perubahan skor HEI subjek sebelum dan sesudah intervensi

Keterangan:

Skor HEl1= sebelum konseling

Skor $\mathrm{HEI}=$ setelah konseling

utama sumber karbohidrat, tingginya asupan buah dan sayur, serta asupan omega-3 yang cukup dapat memberikan proteksi terhadap penyakit kardiovaskular (22).

Di awal penelitian, tidak terdapat perbedaan yang signifikan antara proporsi kualitas diet pasien pada kelompok kontrol dan perlakuan $(p>0,05)$. Terdapat 6 subjek pada kelompok kontrol yang memiliki kualitas diet baik (skor HEI >80), sebanyak 19 responden masuk dalam kategori kualitas diet rata-rata, dan 2 sisanya memiliki kualitas diet yang buruk (skor $\mathrm{HEI}<60$ ). Pada akhir penelitian, kualitas diet 6 responden yang awalnya tergolong baik menurun menjadi rata-rata (Tabel 3, Gambar 1, Gambar 2).

Berbeda dengan kelompok kontrol, kualitas diet subjek pada kelompok perlakuan meningkat secara signifikan setelah pemberian intervensi berupa konseling gizi individu, diskusi kelompok, dan monitoring selama 4 minggu $(p<0,05)$. Sebelum pemberian intervensi seluruh subjek di kelompok perlakuan memiliki kualitas diet yang tergolong rata-rata, namun setelah intervensi ada 5 responden yang berhasil memperbaiki kualitas dietnya menjadi kategori baik. Walaupun kualitas diet 22 responden lainnya tergolong rata-rata, dapat dilihat adanya peningkatan skor ke arah yang lebih baik (Tabel $\mathbf{3}$, Gambar 1). Hal ini membuktikan bahwa pemberian konseling individu dan kelompok dapat memperbaiki kualitas diet diabetis mellitus, terutama dari segi peningkatan asupan buah dan sayuran (Tabel 2). Besarnya tingkat keberhasilan konseling gizi dalam meningkatkan skor HEI pada pasien diabetes mellitus adalah sebanyak 73\% (Tabel 4).

Berbagai penyakit metabolik seperti jantung, darah tinggi, obesitas, dan diabetes mellitus tidak dapat terlepas dari konseling gizi dalam penanganannya. Sebuah penelitian di Brazil mengungkapkan bahwa konseling gizi singkat dapat menurunkan berat badan, tekanan darah lingkar pinggang, kadar gula puasa, kolesterol, dan asupan energi diet pada pasien dengan sindroma metabolik (23).

Hasil penelitian lain di Banjarmasin menunjukkan adanya peningkatan kepatuhan diet dan penurunan kadar gula darah pada pasien diabetes yang mendapat konseling dengan standar diet (24). Hasil penelitian tersebut menguatkan 
penelitian ini, yaitu terjadi peningkatan kepatuhan diet pada pasien diabetes mellitus yang menerima konseling gizi dan kelompok. Hal tersebut ditandai dengan adanya peningkatan asupan berbagai komponen bahan makanan yang telah disepakati seperti buah dan sayur.

Konseling gizi juga telah terbukti dapat menurunkan rasio TG/HDL dan berat badan secara signifikan (25). Penelitian lain juga menyebutkan pasien yang mendapatkan konseling gizi lebih mampu meningkatkan asupan sayuran dan aktivitas fisik, serta menurunkan penggunaan minyak (23). Hal ini sejalan dengan hasil penelitian yang diketahui pada akhir penelitian terdapat peningkatan asupan beberapa jenis makanan seperti sayuran dan buah-buahan. Namun demikian, penurunan penggunaan minyak belum terjadi selama penelitian. Hal ini disebabkan belum ada kesepakatan untuk menurunkan asupan minyak selama proses konseling gizi, mengingat keterbatasan waktu penelitian.

Konseling gizi diketahui memberikan efek yang positif terhadap peningkatan asupan sayur dan buah pada orang dewasa, terlebih lagi pada individu yang memiliki gangguan kesehatan. Berbagai macam model konseling gizi diketahui memberikan dampak positif dalam mengatasi kesulitan terhadap perubahan pola makan individu (26).

Konseling kelompok dipilih menjadi bagian dalam terapi konseling gizi yang diberikan karena dinilai lebih efisien dan memberikan banyak sumber daya dan sudut pandang (8). Beberapa penelitian lain juga menunjukkan adanya perbaikan keluaran terkait gizi seperti berat badan dan indeks massa tubuh dengan attrition rate (kecepatan penurunan suatu periode) sebesar $30 \%$ setelah pemberian konseling kelompok. Penelitian lain juga menyebutkan bahwa pasien diabetes yang menerima gabungan edukasi individu dan kelompok mengalami peningkatan yang lebih besar dalam hal kontrol perilaku, niat untuk mematuhi anjuran gizi, serta kontrol mandiri terhadap kepatuhan diet (9). Konseling gizi secara individu pada penelitian ini diberikan untuk mengantisipasi adanya hal yang tidak dapat diperoleh responden dari konseling kelompok, seperti perhitungan kebutuhan energi dan zat gizi secara individu. Hasil penelitian ini membuktikan kombinasi dari kedua jenis konseling ini dapat memperbaiki kualitas diet pasien diabetes mellitus.

Efek positif konseling kelompok dalam perbaikan kualitas diet dapat dipengaruhi oleh beberapa faktor, di antaranya ada perasaan yang sama, rasa saling memiliki, kesempatan mempraktikkan perilaku baru, keuntungan untuk mendapat timbal balik, keuntungan untuk belajar lebih mendalam dengan mendengarkan dan melihat subjek lainnya, pendekatan pada kehidupan nyata, dan ada tekanan untuk memegang komitmen yang telah disepakati (9). Walaupun demikian, penggunaan metode ini juga belum tentu cocok untuk semua pasien, terutama pasien yang belum memiliki kesiapan untuk berubah (8). Tekanan dalam kelompok mungkin akan memberikan pengaruh pada individu yang tidak memiliki kesiapan masuk dalam kelompok. Mereka dapat mengganggu atau merusak diskusi sebagai aksi perlindungan diri sebelum mereka siap (8). Pada penelitian ini, seluruh responden yang terlibat memiliki kebebasan untuk menolak atau menerima intervensi yang diberikan. Responden yang bersedia menerima intervensi setidaknya berada pada fase pre kontemplasi atau memiliki keinginan untuk berubah. Oleh karena itu, efek negatif konseling kelompok dapat dihindari.

\section{KESIMPULAN DAN SARAN}

Perubahan kualitas diet kelompok kontrol berbeda signifikan dengan perubahan kualitas diet pada kelompok perlakuan. Konseling gizi individu dan kelompok terbukti memperbaiki kualitas diet pada pasien diabetes mellitus. Konsumsi sayur, buah, susu, daging, dan kacang-kacangan mengalami peningkatan yang signifikan pada kelompok perlakuan. Hal ini disebabkan adanya pemberian edukasi diet seimbang diabetes mellitus pada sesi konseling yang dijalani oleh subjek.

Diperlukan observasi lebih lanjut mengenai efek konseling gizi terhadap perubahan kualitas diet pasien diabetes mellitus dalam jangka waktu yang lebih panjang dan dengan jumlah subjek yang lebih besar. Metode gabungan konseling individu 
dan kelompok dapat menjadi pertimbangan ahli gizi sebagai salah satu alternatif terapi diet diabetes mellitus yang murah dan efisien.

\section{RUJUKAN}

1. Price S, Wilson L. Patofisiologi: konsep klinis proses-proses penyakit (Edisi Bahasa Indonesia). Brahm $\mathrm{U}$, Hartono $\mathrm{H}$, Wulansari $\mathrm{P}$, Maharani D, editors. Jakarta: Penerbit Buku Kedokteran EGC; 2005.

2. Mangou A, Grammatikopoulou MG, Mirkopoulou D, Sailer N, Kotzamanidis C, Tsigga M. Associations between diet quality, health status and diabetic complications in patients with type 2 diabetes and comorbid obesity. Endocrinología y Nutrición. 2012. p. 109-16.

3. de León AC, Rodríguez JC, Coello SD, Pérez Mdel C, Díaz BB, Alamo CB, et al. Lifestyle and treatment adherence of type 2 diabetes mellitus people in the Canary Islands. Rev Esp Salud Pública. 2009; 83:567-75.

4. Moreau A, Aroles V, Souweine G, Flori M, Erpeldinger $\mathrm{S}$, Figon $\mathrm{S}$, et al. Patient versus general practitioner perception of problems with treatment adherence in type 2 diabetes: from adherence to concordance. Eur J Gen Pr. 2009;15:147-53.

5. Hann C, Rock C, King I, Drewnowski A. Validation of the healthy eating index with use of plasma biomarkers in a clinical sample of women. Am J Clin Nutr. 2001;74(4):479-86.

6. Association AD. Nutrition recommendations and interventions for diabetes: a position statement of the American Diabetes Association. Diabetes Care. 2008.

7. Indonesia PE. Konsensus diabetes mellitus Tipe 2 Indonesia. Jakarta: Perkumpulan Endokrinologi Indonesia; 2011.

8. Jacobs E, Masson R, Harvill R, Schimmel C. Group counseling strategies and skills (7th ed). Belmont, CA: Brooks/Cole; 2012.

9. Spahn JM, Reeves RS, Keim KS, Laquatra I, Kellogg M, Jortberg B, et al. State of the evidence regarding behavior change theories and strategies in nutrition counseling to facilitate health and food behavior change. J Am Diet Assoc. 2010;110(6):879-91.

10. Reedy J, Krebs-Smith SM, Bosire C. Evaluating the food environment. Application of the healthy eating index-2005. Am J Prev Med. 2010;38:465-71.

11. Maghsoudi Z, Azadbakht L. How dietary patterns could have a role in prevention, progression, or management of diabetes mellitus? review on the current evidence. J Res Med Sci. 2012;17(7):694-709.

12. Mcnaughton SA, Dunstan DW, Ball K, Shaw J, Crawford D. Dietary quality is associated with diabetes and cardio-metabolic risk factors. Analysis. 2009;734-42.

13. American Diabetes Association. Nutrition recommendations and interventions for diabetes: a position statement of the American Diabetes Association. Diabetes Care. 2008. p. S61-78.

14. Franz M, Bantle J, Beebe $C$, Brunzell J, Chiasson $\mathrm{J}-\mathrm{L}, \mathrm{GargA}$, etal. Evidence-based nutrition principles and recommendations for the treatment and prevention of diabetes and related complications. Diabetes Care. 2002;25(1):148-199.

15. Olendzki B, Speed C, Domino F. Nutritional assessment and counseling for prevention and treatment of cardiovascular disease. Am Fam Physician [Internet]. 2006;73(2):257-64. Available from: http://www.ncbi.nlm.nih.gov/ pubmed/16445271

16. Larsson S, WolkA. Magnesium intake and risk of type 2 diabetes: a meta-analysis. J Intern Med. 2007;262(2):208-14.

17. De Munter JSL, Hu FB, Spiegelman D, Franz $M$, Van Dam RM. Whole grain, bran, and germ intake and risk of type 2 diabetes: a prospective cohort study and systematic review. PLoS Medicine. 2007. p. 1385-95.

18. Van Dam R, Willett W, Rimm E, Stampfer M, Hu F. Dietary fat and meat intake in relation to risk of type 2 diabetes in men. Diabetes Care. 2002;25(3):417-24.

19. Murakami K, Okubo H, Sasaki S. Effect of dietary factors on incidence of type 2 diabetes: a systematic reviews of cohort studies. J Nutr Sci Vitaminol. 2005;51:292-310. 
20. Liu S, Choi HK, Ford E, Song Y, Klevak A, Buring $\mathrm{JE}$, et al. A prospective study of dairy intake and the risk of type 2 diabetes in women. Diabetes Care. 2006;29(7):1579-84.

21. Elwood PC, Pickering JE, lan Givens D, Gallacher JE. The consumption of milk and dairy foods and the incidence of vascular disease and diabetes: An overview of the evidence. Lipids. 2010;45:92539.

22. Hu F, Willett W. Optimal diets for prevention of coronary heartdisease. JAMA. 2002;288(20):2569_ 78.

23. Sartorelli D, Sciarra E, Franco L, Cardoso M. Beneficial effect of short-term nutritional counseling at the primary health-care level among Brazilian Adult. Public Health Nutr. 2005;8(7):820-5.
24. Magdalena. Pengaruh konseling gizi menggunakan standar diet terhadap pengetahuan dan kepatuhan diet pada pasien diabetes mellitus di RSUD Ulin Banjarmasin. Universitas Gadjah Mada; 2005.

25. Pimentel GD, Arimura ST, de Moura BM, Silva MER, de Sousa MV. Short-term nutritional counseling reduces body mass index, waist circumference, triceps skinfold and triglycerides in women with metabolic syndrome. Diabetol Metab Syndr. 2010;2:13.

26. Pomerleau J, Lock K, Knai C, McKee M. Interventions designed to increase adult fruit and vegetable intake can be effective: a systematic review of the literature. J Nutr. 2005;135(10):2486-95. 